\title{
A comparative study of low dose vaginal misoprostol and dinoprostone gel for induction of labour at term of pregnancy
}

\author{
Kalpana $^{1}$, Priya Sharma ${ }^{1}$, Amit Kaushik ${ }^{2}$, Priyanka Rao ${ }^{1}$, Neelam Swaroop ${ }^{1}$, Neetu Singh $^{1}$ \\ ${ }^{1}$ Department of Obstetrics and Gynaecology, Uttar Pradesh University of Medical, Saifai, Etawah, Uttar Pradesh, India \\ ${ }^{2}$ Department of Community Medicine, Uttar Pradesh University of Medical, Saifai, Etawah, Uttar Pradesh, India
}

Received: 28 October 2016

Revised: 09 November 2016

Accepted: 30 November 2016

\author{
*Correspondence: \\ Dr. Kalpana, \\ E-mail: doc.kalpana@yahoo.com
}

Copyright: (c) the author(s), publisher and licensee Medip Academy. This is an open-access article distributed under the terms of the Creative Commons Attribution Non-Commercial License, which permits unrestricted non-commercial use, distribution, and reproduction in any medium, provided the original work is properly cited.

\begin{abstract}
Background: The aim of this study was to compare the low dose of vaginal misoprostol and dinoprostone gel for the induction of labour at term of pregnancy.

Methods: The study was conducted on 90 women, randomized into two groups, each group having 45 women. First group received misoprostol per vaginally and second group received the dinoprostone gel. The duration of induction to delivery interval, mode of delivery and complications related to labour or foetus were recorded.

Results: The mean induction to delivery interval in the misoprostol group was $11.68 \pm 4.49$ hours and in the dioprostone gel group was $14.85 \pm 7.08$ hours. Applying the modified t-test, this difference is statistically significant ( $\mathrm{P}$ value 0.004 ). Thus misoprostol leads to early labour and early delivery as compared to dinoprostone gel.

Conclusions: As shown in this study, vaginal misoprostol is highly effective induction agent with no adverse effect on the outcome of labour as compared to dinoprostone gel.
\end{abstract}

Keywords: Dinoprostone gel, Labour induction, Labour analgesia, Misoprostol

\section{INTRODUCTION}

Mostly labour set in spontaneously but for various obstetrical and medical indications it needs to be in which prolongation of pregnancy would zeopridize fetal or maternal wellbeing and in which there are no contraindication to vaginal delivery. Many studies have shown the advantages of using vaginal prostaglandins in cervical ripening and labour induction in term of reduce induction delivery interval and lower operative rate. ${ }^{1,2}$ Dinoprostone (PGE2) is drug of choice and accepted for labour induction at term although safe and effective, it is expensive and require refrigeration for storage.

Misoprostol is a synthetic prostaglandins (PGE1) analogue; it is rapidly absorbed by gastrointestinal tract. It then undergo de-esterification to its free acids which is responsible for its clinical activity. Total systemic bioactivity of vaginal misoprostol is three times greater than that of orally administered misoprostol. Misoprostol is extensively used because it is effective, inexpensive easily store, not affected by temperature and need no refrigeration for its storage or no need of needle or syringes for administration. It has in comparison to the other prostaglandins minimal affect on cardiovascular system and bronchial tree smooth muscles and so can be safely used in hypertensive and asthmatic patient. The present study is aimed to compare the efficacy, safety and cost effectiveness of misoprostol with dinoprostone gel for induction of labour at term of pregnancy.

\section{METHODS}

This prospective study was undertaken in Uttar Pradesh University of medical science, Saifai, Etawah, written informed consent was obtain from all women who participated in the study. All women attending the labour room at term (37-42weeks) pregnancy, with a singleton 
fetus in cephalic presentation, intact membrane, Bishop's score $>4$ and voluntary to participate in the trial were included in the study. Grand multipara women with caesarean or other surgical scars on uterus multifetal gestation non reassuring fetal heart tracing, thyrotoxicosis, heart disease, bronchial asthma, sickle cell disease and known hypersensitivity to prostaglandins were excluded from the study.

A total of 90 women were randomized into two group of 45 each, The first group of 45 women received $25 \mathrm{ug}$ of misoprostol (PGE1) per vaginally every 6 hours for a maximum of five dose. Second group received $0.5 \mathrm{mg}$ dinoprostone gel every six hours for a maximum of three doses (PGE2) group. Cervical evaluation was done using Bishop's score $=8$ end point of study was ripening of cervix or initiation of active labour though evaluation continue till delivery to record the duration of induction delivery interval, mode of delivery, any labour complication and fetal outcome.

Statistical analysis was done using student t-test, $\mathrm{s}^{2}$ test comparing dose of misoprostol required induction to active labour interval, induction delivery interval mode of delivery, labour complication.

\section{RESULTS}

Table 1: Demographic variables.

\begin{tabular}{|lll|}
\hline Variables & $\begin{array}{l}\text { Vaginal } \\
(\text { PGE1) } \\
n=45\end{array}$ & $\begin{array}{l}\text { Vaginal } \\
(\text { PGE2) } \\
n=45\end{array}$ \\
\hline Average age (years) & 25 & 24 \\
\hline Average height $(\mathrm{cm})$ & 152.5 & 150 \\
\hline Average weight $(\mathrm{kg})$ & 61 & 59 \\
\hline Primigravida & $25(55.5 \%)$ & $24(53.33 \%)$ \\
\hline Multigravida & $\begin{array}{l}20 \\
(44.44 \%)\end{array}$ & $21(46.6 \%)$ \\
\hline $\begin{array}{l}\text { Average gestation } \\
\text { (weeks) }\end{array}$ & $\begin{array}{l}38.9+/- \\
1.58\end{array}$ & $38.1+/-2.03$ \\
\hline
\end{tabular}

Table 2: Indications for induction of labour and their distribution in both groups.

\begin{tabular}{|c|c|c|}
\hline Indication & $\begin{array}{l}\text { Vaginal } \\
\text { misoprostol } \\
(n=45) \\
\text { no. }(\%)\end{array}$ & $\begin{array}{l}\text { Vaginal } \\
\text { dinoprostone } \\
\text { gel }(\mathrm{n}=45) \\
\text { no. } \\
(\%)\end{array}$ \\
\hline Post dated & 2453.33 & 2248.80 \\
\hline PIH & 1124.40 & 1328.80 \\
\hline IUGR & 511.10 & 613.30 \\
\hline PROM & 36.60 & 24.40 \\
\hline oligohydramnios & 24.40 & 24.40 \\
\hline
\end{tabular}

A total of 90 women were selected for study and 45 women were assigned to vaginal misoprostol group and another 45 women were assigned to dinoprostone gel group. The demographic characteristics of two groups study population include maternal age and gestational age were similar in both group (Table 1). Indications for induction of labour were similar in both groups, $53.33 \%$ patients were induced for post datism in the study group, as compared to $48.88 \%$ in control group. Other indication for induction was intrauterine growth retardation, premature rupture of the membrane and oligohydramnios (Table 2).

Table 3: Mode of delivery and their incidence in both groups.

\begin{tabular}{|lll|}
\hline & $\begin{array}{l}\text { Misoprostol } \\
\text { (PGE1) }(\mathbf{n = 4 5}) \\
\text { no. }(\%)\end{array}$ & $\begin{array}{l}\text { Vaginal } \\
\text { dinoprostone } \\
\text { gel (PGE2) } \\
(\mathbf{n = 4 5}) \text { no. }(\%)\end{array}$ \\
\hline $\begin{array}{l}\text { Spontaneous } \\
\text { vaginally }\end{array}$ & 3373.30 & 3271.10 \\
\hline Caesarean & 817.70 & 1022.20 \\
\hline Vaccum & 48.80 & 36.60 \\
\hline
\end{tabular}

Table 4: Outcome of labour in the vaginally misoprostol and dinoprostone gel group.

\begin{tabular}{|lll|l|}
\hline & $\begin{array}{l}\text { Misoprostol } \\
(\text { PGE1) } \\
(\mathbf{n = 4 5})\end{array}$ & $\begin{array}{l}\text { Vaginal } \\
\text { dinoprostol } \\
\text { gel (PGE2) } \\
(\mathbf{n = 4 5 )}\end{array}$ & P value \\
\hline $\begin{array}{l}\text { Induction } \\
\text { interval to } \\
\text { cervical } \\
\text { ripening }\end{array}$ & $\begin{array}{l}5.78 \pm 2.34 \\
\text { hrs } \\
\text { (hrs) }\end{array}$ & $\begin{array}{l}6.78 \pm 4.51 \\
\text { hrs }\end{array}$ & 0.017 \\
\hline $\begin{array}{l}\text { Induction } \\
\text { delivery } \\
\text { interval }\end{array}$ & $11.68 \pm 4.49$ & $14.8 \pm 7.08$ & 0.004 \\
\hline
\end{tabular}

Table 5: Neonatal outcome in vaginal misoprostone and dinoprostone gel.

\begin{tabular}{|lcc|}
\hline & $\begin{array}{c}\text { PGE1 group } \\
\text { Mean } \pm \text { SD }\end{array}$ & $\begin{array}{c}\text { PGE2 group } \\
\text { Mean } \pm \text { SD }\end{array}$ \\
\hline $\begin{array}{l}\text { Mean apgar } \\
\text { score at one } \\
\text { minute }\end{array}$ & $7.9 \pm 0.2$ & $7.5 \pm 0.2$ \\
\hline $\begin{array}{l}\text { Mean apgar } \\
\text { score at five } \\
\text { minute }\end{array}$ & $8.5 \pm 0.2$ & $8.4 \pm 0.2$ \\
\hline $\begin{array}{l}\text { Birth weight } \\
(\text { Kg) }\end{array}$ & $2.83 \pm 0.95$ & $2.67 \pm 0.38$ \\
\hline
\end{tabular}

The mean induction to delivery interval in the study group was $11.68 \pm 4.49$ hours and in the control group was $14.85 \pm 7.08$ hours. Applying the modified t- test, this difference was statistically significant $(\mathrm{P}$ value $=$ 0.004) (Table 4). Thus misoprostol leads to early labour and early delivery as compared to dinoprostone gel. Caesarean section were similar in both group (Table 3 ), 
no significant difference was observed in mean birth weight of neonates in both groups, mean Apgar score at one and five minute was also found to be similar in both group (Table 5). The mean over all induction cost in misoprostol group was much less in contrast to dinoprostone gel group.

\section{DISCUSSION}

The two groups did not differ significantly with respect to baseline characteristics like gravid and gestational age etc (table -1). The finding of our study were consistent with the finding reported by Shivarudraiah and Palaksha et al, in our study post datism was most common indication for induction (53.33\%) and (44.44\%) I group A and group B respectively and followed by pregnancy induced hypertension $24.44 \%$ and $33.33 \%$ in group A and Group $\mathrm{B}$ respectively. ${ }^{1}$ Grcagsons et al2 in their study showed that $95 \%$ patient in mesprostol group and $94 \%$ in cerviprem group were induced for post datism. Simultaneously Sheela $\mathrm{CN}$ et al demonstrated that post datism (36\% and $32 \%$ respectively) and pregnancy induced hypertension (22\% and $26 \%$ respectively) in both groups. $^{3}$

The mean time taken for onset of labour was less in misoprostol group $(5.87 \pm 2.34)$ hours as compared to cerviprem group $(6.78 \pm 4.51)$ hours. The mean induction to delivery interval was less in the misoprostol group $(10.20 \pm 3.5)$ vs $(14.27 \pm 5.5)$ hours. The mean induction delivery interval in the study group was at least 4 hour shorter than control group. And this difference was statistically higher significant. The finding of our study was consistent with finding reported by Murthy Bhasker Murthy K. Other reported studies, also had same observation. $^{4-6}$ Thus misoprostol reduces the mean duration of labour which reduces the duration of suffering of a patient in labour and also provides a fast delivery which is required in case of premature rupture of membrane, eclampsia and fetal distress. Maternal side effects were minimal in both groups. No significant difference was observed in in mean birth weight of neonates in both groups. Mean Apgar score an one minute and five minute was also found the similar in both groups.

The mean overall induction cost in misoprostol group was much less In contrast to cerviprem gel group. As misoprostol does not need of refrigeration, its affordability as well as its availability in the peripheral area is more than the cerviprem gel.

\section{CONCLUSION}

The use of prostaglandin provide an effective method for achieving the induction of labour on the basis of our study misoprostol $25 \mathrm{mg}$ vaginally is highly effective induction agent with no adverse effect on the outcome of labour as compared to the dinoprostone gel.

Finally misoprostol is cheaper than dinoprostone, easy to administer by intravaginal route and does not require refrigeration. This indicates that the misoprostol is better, effective and safe alternative drug for induction of labour.

Funding: No funding sources

Conflict of interest: None declared

Ethical approval: Not required

\section{REFERENCES}

1. Shivarudraiah G, Palaksha MA. A randomized controlled trial comparing low dose vaginal misoprostol and dinoprostone gel for labor induction. J Obstet Gynaecol India. 2011;2:153-60.

2. Greagson S, Waterstone M., Norman I., Murrells T. A randomized controlled trial comparing low dose vaginal misoprostol and dinoprostone vaginal gel for inducing labour at term. BJOG. 2005;112:438-44.

3. Sheela CN, Mhaskar A, George S. Comparison of vaginal misoprostol and oral misoprostol with intracervical dinoprostol gel for induction of labour at term. J Obstet Gynecol India. 2007 July/Aug;57(4):327-30.

4. Latika S, Biswajit C. Comparison of prostaglandin E1 (Misoprostol) with prostaglandin E2 (Cerviprime) for labour induction. J Obstet Gynecol India. 2004;54(2):139-42.

5. Murthy BK, Arkalgud MS. Misoprostol alone versus a combination of cerviprime and oxytocin for induction of labour. J Obstet Gynecol India. 2006;56(5):413-6.

6. Ozkan S, Caliskan E. Comparative safety and efficacy of vaginal Misoprostol versus cerviprime vaginal insert in labour induction at term: a randomized trial. Arch Gynecol Obstet. 2009;280(1):19-24.

7. Cheng SY, Ming H, Lee JC. Titrated oral compared with vaginal misoprostol for labor induction: a randomized controlled trial. Obstet Gynecol. 2008;111:119-25.

Cite this article as: Kalpana, Sharma P, Kaushik A, Rao P, Swaroop N, Singh N. A comparative study of low dose vaginal misoprostol and dinoprostone gel for induction of labour at term of pregnancy. Int J Reprod Contracept Obstet Gynecol 2017;6:207-9. 